\title{
Tom Scott
}

\section{The Reformation and Modern Political Economy: Luther and Gaismair compared"}

In a fragment of the original notebooks for the Critique of Political Economy of 1858, known as the Grundrisse, Karl Marx referred in passing to Martin Luther as "the oldest German political economist" 1 . His remark was based upon Luther's observation in On Trade and Usury (1524): „Das kann man nicht leugnen, dass Kaufen und Verkaufen ein nötig Ding ist, das man nicht entberen und wol christlich brauchen kann...", in other words, that production for exchange alongside production purely for consumption was a necessary feature of human life. In doing so, Marx sacrificed accuracy to apophthegm: while his verdict may possibly hold true for the German lands themselves, it ignores the decisive contribution of medieval scholastic writers, principally though not exclusively in Italy, to the development of economic thought ${ }^{2}$. For the subsequent historiography of the German Reformation, however, Marx's description of Luther has had particularly unfortunate consequences. In the first place, it has subjected Marxist economists and historians to the compulsion to construct an unbroken and dialectically ineluctable tradition stretching from Luther's initial attack on the feudal Catholic church and his objective embodiment of the interests of an emerging bourgeoisie to modern free-market economies under capitalism. In the second, it has encouraged non-Marxists either to ignore the contribution of the German Reformation in general and Luther in particular to modern political economy, or else to reaffirm Luther's essentially theological concern with social and economic issues which by definition precluded him from analyzing, let alone understanding, the profound transformations of his own day in their own terms.

\footnotetext{
* The text presents a revised version of the lecture delivered in Munich. For critical and helpful comments I am grateful to Peter Blickle, Tom Brady, Erik Midelfort, and Manfred Schulze.

1 Karl Marx, Grundrisse (Berlin 1953) 891. The quotation is part of the fragments of the original text of „Zur Kritik der Politischen Ökonomie“, which are not included in the English translation (Harmondsworth 1973).

2 Cf. the contributions of Raymond de Roover, Business, Banking and Economic Thought in Late Medieval and Early Modern Europe. Selected Studies of Raymond de Roover. Ed.Julius Kirshner (Chicago, London 1974).
} 
Instead, the debate among non-Marxists over the links between Protestantism and capitalism has followed other, well-trodden paths, which led attention away from the issues of the early Reformation in the German-speaking lands to the later history of international Protestantism in the guise of Calvinism and the Puritans of England and North America. Apart from over-ingenious exegesis of Luther's concept of calling or vocation (Beruf), the pioneers of this scholarly tradition Max Weber and Ernst Troeltsch - marginalized the role of German Protestantism (by which they essentially meant Lutheranism) in the history of bourgeois liberty, or else regarded its contribution as reactionary. Yet there are, I believe, good reasons to look afresh at the German Reformers' treatment of social and economic issues: both to see whether there are connections to be made between the Reformers' own concerns and the policies adopted by the German princely territories before the age of classical economics, that is to say, the doctrines known as mercantilism or, in its German variant, cameralism; and to examine whether the Reformers' response to the economic dislocations of their day was purely conventional or displayed insight into the causes and trajectory of those transformations.

It is self-evident that the early Reformers, both clerical and lay, interpreted the world in the light of Scripture. The message of the Gospel - good neighbourliness, brotherly love, sharing one's goods, caring for the poor - may be seen as the theological-ethical equivalent of the medieval maxims of auskömmliche, bürgerliche, or ziemliche Nabrung, terms which do not translate precisely into English, but which see man's end in the satisfaction of immediate needs, production for consumption, and the principle of self-sufficiency, rather than in exchange, accumulation, or the search for profit ${ }^{3}$. Those Reformers who gave concrete expression to their vision of the Christian commonweal looked back, almost without exception, to a primarily agrarian world of small communities living by the sweat of their own brow, tilling the soil in communion with nature. In such a society handicrafts played a subordinate role, commerce or exchange was restricted to necessities, money was sterile, as Aristotle and the Church fathers had taught, and the profitmotive was unknown. Allied to the strong undercurrent of autarky was frequently a streak of moral rigorism, the whole informed by strains of administrative rationalism characteristic of the Renaissance.

The contradictions in such a harmonizing picture need hardly be spelled out. The lessons to be drawn from the Gospel were not clear-cut. Only a minority, the Anabaptists (and not even all of them), fully embraced the common ownership of goods, although the principle of brotherly love might seem to enjoin it. This question became acute during the Peasants' War, in which the vocal and unmistakable protests of tenants with revocable leases at the rapacity of their feudal lords must be set against the threat to their livelihood as family groups which proposals to expropriate farms and collectivize agriculture, voiced by certain radicals, ostensibly

3 Cf. Renate Blickle, Nahrung und Eigentum als Kategorien in der ständischen Gesellschaft, in: Winfried Schulze (ed.), Ständische Gesellschaft und Mobilität (Schriften des Historischen Kollegs, Kolloquien 12, Munich 1988) 73-93. 
posed ${ }^{4}$. How social relations in the Reformers' rural arcadia were to be configured - where the balance between individual property rights and collective-communal obligations was to be struck - was left unanswered.

I propose to pursue these issues by comparing the economic thought of Martin Luther and Michael Gaismair. The comparison is less outré than it might appear. It may reveal significant congruences as well as contrasts between the vision of the supreme clerical Reformer of Evangelical Protestantism and that of the exponent of a radical Christian Utopia directly influenced by the Reformed Protestant tradition of Zwingli and his followers in southern Germany.

The comparison gains piquancy, moreover, because Luther and Gaismair came from remarkably similar backgrounds, and lived and worked in landscapes undergoing profound economic and social transformation in the early sixteenth century, areas stamped by the rise of large-scale mining enterprises. Both men were acutely alive to these changes (even if they viewed them with apprehension), but each sought to work out his response to the changes rather than ignore them.

My argument, therefore, attempts to go beyond both the outworn distinction between the subjective intentions and objective consequences of their thinking, once so beloved of East German Marxists, and the banal recognition that Luther and Gaismair, in common with all other Reformers, were hostile to the manifestations of early capitalism. Rather, I am concerned to discover how far Luther and Gaismair understood the underlying mechanisms of the market and of capital accumulation. My procedure is to begin by exploring the remarkable similarities in Luther's and Gaismair's backgrounds, before analyzing certain important strands in their thought, and finally setting their thought in a broader conceptual framework.

\section{I.}

Both men were natives of regions which were experiencing the impact of major capital investment in mining and smelting precious and base metal ores by large business enterprises who used their financial clout to monopolize both production and distribution: Luther in Saxony, which on its southern border with Bohe-

${ }^{4}$ Cf. the essays by James Stayer and Marion Kobelt-Groch, in: Hans-Jürgen Goertz (ed.), Alles gehört allen. Das Experiment Gütergemeinschaft vom 16. Jahrhundert bis heute (Munich 1984); James M. Stayer, The German Peasants' War and Anabaptist Community of Goods (McGill-Queen's Studies in the History of Religion 6, Montreal, Kingston, Ont., London, Ont., Buffalo, NY 1991). Whether Thomas Müntzer's famous dictum, extracted under torture, omnia sunt communia, amounts to a demand for the complete abolition of private property has been questioned by Tom Scott, Thomas Müntzer. Theology and Revolution in the German Reformation (Houndmills, London 1989) 170ff., and by Frank Ganseuer, Der Staat des "gemeinen Mannes“. Gattungstypologie und Programmatik des politischen Schrifttums von Reformation und Bauernkrieg (Europäische Hochschulschriften, Series III 228, Frankfurt a. M., Bern, New York 1985) 84-90. 
mia had extensive reserves of silver, together with the copper and lead commonly found in argentiferous rock, as well as copper ore from the copper-shale fields of the county of Mansfeld in northern Thuringia; Gaismair in Tirol, where northern Tirol contained the richest silver mines in western Europe with their centre in Schwaz, alongside considerable deposits of salt in saliferous rock around Hall, Hallein and Reichenhall, while South Tirol, over the Brenner, held resources of silver but more particularly of lead glance (galena), used in the smelting of silver ore.

Tom Brady has spoken of Luther as the child of a ,transition zone between the older, more rooted societies of western and southern Germany and the classic colonial lands of the German East“, who grew up in a "relatively fluid society, a Saxony poised between its colonial past and its future plunge into the ,New Serfdom" and absolutism", with the assumption that these circumstances coloured his thinking on politics and society ${ }^{5}$. But Gaismair, too, was the child of a frontier area, with Tirol as the main landborne artery of trade from Italy and the Mediterranean to the lands north of the Alps, its ethnically German population marching with Italian-speakers to the south, but intermingled under the jurisdiction of the Austrian Habsburgs, and the bishops of Brixen/Bressanone and Trent, and abutting the Venetian terraferma, where Gaismair sought refuge in exile.

Although Tirol was more obviously a commercial crossroads than Saxony, both regions had fully commercialized economies quite apart from their mining industries. By the sixteenth century Saxony was a major cultivator of the dyeplant woad, grown in the district surrounding Erfurt, which throve in symbiosis with a burgeoning textile sector, producing mostly linen, but also woollen cloth on its eastern border with Lusatia. Its rural economy was penetrated by the putting-out system, the principal manifestation of early capitalism in Germany; country crafts and manufactures flourished. And, despite their northern latitude, Saxony (along the Elbe) and Thuringia (south of Erfurt) were areas of viticulture of more than local significance: there was a lively interregional trade.

Tirol's economy, not least on account of its topography, was less exposed to the putting-out system. It was a land of commerce rather than of manufactures. Yet in South Tirol on the slopes of the Adige valley viticulture was extensive, particularly for red wines on the southern marches with the Trentino, which were sent north to the major cities of Upper Germany?. But on the valley floor, as Gais-

5 Thomas A. Brady, Jr., Luther and the State: The Reformer's Teaching in Its Social Setting, in: James D. Tracy (ed.), Luther and the Modern State in Germany (Sixteenth Century Essays and Studies 7, Kirksville, MO 1986) 38.

${ }^{6}$ Tom Scott, Economic Landscapes, in: Bob Scribner (ed.), Germany. A New Social and Economic History, vol. 1 (London, New York, Sydney, Auckland 1996) 12, 15, 17; Wieland Held, Zwischen Marktplatz und Anger. Stadt-Land-Beziehungen im 16. Jahrhundert in Thüringen (Weimar 1988) $111 \mathrm{ff}$., $174 \mathrm{f}$.

7 Cf. Josef Nössing, Die Bedeutung der Tiroler Weine im Mittelalter, in: Christhard Scbrenk, Hubert Weckbach (eds.), Weinwirtschaft im Mittelalter. Zur Verbreitung, Regionalisierung und wirtschaftlichen Nutzung einer Sonderkultur aus der Römerzeit (Quellen und Forschungen zur Geschichte der Stadt Heilbronn 9, Heilbronn 1997) 193-203. 
mair's Tirolean Constitution was to make plain, the potential existed for an intensified agrarian regime supplying more than purely local markets. In both Saxony and Tirol, therefore, it was not merely the presence of mining but the growth of a commercialized and diversified rural economy as a whole which made issues of capital investment, credit and interest, the organization of production, and access to markets and distribution of immediate importance.

Luther the Saxon and Gaismair the Tirolean, moreover, shared remarkably similar family histories. Luther's father Hans had been excluded as a younger son in an area of impartible inheritance from taking over the family farm. As a result, he sought his fortune in the copper mines, moving from Eisleben to Mansfeld to lease at first one, and then six, mines. Beginning as a small investor or shareholder (Gewerke), working his own stake, Hans Luther advanced to the rank of an independent mine-owner, advising the Mansfeld counts on mining questions and, despite financial difficulties in mid-career, dying a relatively wealthy man in $1530^{8}$. Luther's family circle stood in close contact with mineowners who were close to the Mansfeld court ${ }^{9}$. His three sisters all married into mineowning families in Mansfeld, where his brother Jakob was also active, running up sizeable debts to putters-out on his mining investments ${ }^{10}$. Luther, therefore, experienced at first hand the social dislocation which the mining industry engendered, but also, of course, the potential riches which mining could bring even to the small man. It is doubtful whether Luther had any direct knowledge of the mining and smelting processes themselves, though he was certainly aware of the increasing concentration of ownership in a few hands, culminating, in the case of Mansfeld, in a new mining ordinance in 1536 which reserved allocation of mining shares exclusively to the counts, prompting considerable discontent amongst the existing shareholders, including Luther's brother Jakob, which was to last for several decades ${ }^{11}$. Luther himself, perhaps understandably, forsook any personal involvement (turning down an offer of mining shares from the Saxon elector in 1536), not least on the grounds that they were a lottery, whose rewards had not been gained by hard work $^{12}$.

${ }^{8}$ Günter Fabiunke, Martin Luther als Nationalökonom (Akademie der Wissenschaften zu Berlin, Schriften des Instituts für Wirtschaftsgeschichte 15, Berlin 1963) 26.

9 Dieter Stievermann, Sozial- und verfassungsgeschichtliche Voraussetzungen Martin Luthers und der Reformation - der landesherrliche Rat in Kursachsen, Kurmainz und Mansfeld, in: Volker Press, Dieter Stievermann (eds.), Martin Luther. Probleme seiner Zeit (Spätmittelalter und Frühe Neuzeit. Tübinger Beiträge zur Geschichtsforschung 16, Stuttgart 1986) 169-170, 172; Ekkehard Westermann, Der wirtschaftliche Konzentrationsprozeß im Mansfelder Revier und seine Auswirkungen auf Martin Luther, seine Verwandten und Freunde, in: Rosemarie Knape (ed.), Martin Luther und der Bergbau im Mansfelder Land (Eisleben 2000) 75.

10 Hanns Freydank, Martin Luther und der Bergbau (Bilder aus der Mansfelder Vergangenheit 4, Eisleben 1939) $40 \mathrm{f}$.

11 Westermann, Wirtschaftlicher Konzentrationsprozeß $78 \mathrm{f}$.

12 Freydank, Luther und der Bergbau, 60. In his table talk Luther disclaimed any knowledge of mining technology. D. Martin Luthers Werke. Kritische Gesamtausgabe [WA], Tischreden [TR], 6 vols. (Weimar 1912-21) 2, 556, (No. 2629b). 
Gaismair, too, came from a moderately prosperous peasant family with holdings around Sterzing/Vipiteno in South Tirol at the foot of the Brenner. His father Jakob had begun to invest as a small shareholder in the mines of South Tirol before the turn of the century, and he was followed by his three sons, including Michael, and other Gaismair kin. These investments underwent fluctuating fortunes, and were, it seems, confined to the mining districts of South Tirol, which were less lucrative than those of North Tirol, yielding more lead glance than silver. That in itself was significant, given lead glance's indispensable role in smelting by liquation, for large investors and trading companies with their clutches firmly upon the rich seams of silver around Schwaz, began to extend their reach south of the Brenner in order to control the necessary supplies of lead glance in Sterzing and elsewhere. The mining shareholders found themselves squeezed out by the large mine-owners and capitalist entrepreneurs, many of whom were not natives of Tirol $^{13}$.

In his Territorial Constitution Gaismair reacted against this development, which he himself witnessed, with alarm, insisting that the interests of native shareholders be safeguarded. Whether Gaismair ever made much money out of his mining stakes is hard to tell; his decision to pursue a career as a territorial official, as clerk to the Austrian governor of South Tirol, was made possible by his legal training (though we do not know where he studied), rather than driven by financial necessity ${ }^{14}$.

Here, then, were two men, born into areas of social and economic transformation, from families directly exposed to those changes (for good or for ill), but who were destined for clerical - in the old sense, that is, clerkly - careers: Luther initially as a student of law, but whose famous experience in a storm near Stotternheim drove him into the monastic life; Gaismair by choice as an official, until his temperament caused him to fall out with his employer. There is no doubt that their circumstances and their background influenced their thinking on social and economic issues - Luther indirectly, Gaismair directly, culminating in the Territorial Constitution.

No other Reformers, whether clerical or lay, could lay claim to a background which so combined regional and family experience, except possibly for Jakob Strauss. Strauss is an interesting figure in this regard, not merely because he began his reforming career in Hall in Tirol, only to be kicked out by the Austrian authorities, before settling in Saxony as preacher in Eisenach, but because he ad-

13 On Gaismair's family background and involvement in mining cf. fundamentally Angelika Bischoff-Urack, Michael Gaismair. Ein Beitrag zur Sozialgeschichte des Bauernkrieges (Vergleichende Gesellschaftsgeschichte und politische Ideengeschichte der Neuzeit 4, Innsbruck 1983) esp. part 2.

14 Ibid. part 3. Her hypothesis, that Gaismair studied at either Bologna or Padua, is contemptuously dismissed by Giorgio Politi, I sette sigilli della „Landesordnung“. Un programma rivoluzionario del primo Cinquecento fra equivoca e mito [part 1], in: Annali dell' Istituto storico italo-germanico in Trento 12 (1986) $30 \mathrm{f}$., because the surviving matriculation lists do not contain his name. But the Paduan rolls are incomplete! Exactly the same problem arises in trying to pin down Thomas Müntzer's places of study. Cf. Scott, Müntzer 3, 5. 
dressed the issue of interest-taking head-on. It should be cautioned, however, that Strauss's denunciation of interest-payments (in principle, though not in practice, no more radical than Luther's) was shaped not by any experience of speculation or profiteering in mining but by his observations of the monastic institutions and the management of their landed estates around Eisenach ${ }^{15}$.

II.

Consideration of Luther's social and economic thought has customarily focused on two components:

1. His concept of calling or vocation (Beruf), which sanctifies not only life in this world, but work itself as service to one's neighbour, while at the same time rejecting as useless the non-productive life of the monk or beggar.

2. His attitude towards mercantile and entrepreneurial activity in general, and towards interest-taking in particular, a theme which he explored at the outset of his career, first summarized in his tract On Trade and Usury of 1524, and to which he returned towards the end of his life in 1540 when he published To the Parish Clergy, to Preach against Usury.

These strands may point to the core of Luther's thought but of themselves they hardly constitute its essence. This is not the place to dwell upon Max Weber's interpretation of Luther's choice to render the passage in Ecclesiasticus XI, v.20: "Bleibe in Gottes wort und vbe dich drinnen vnd beharre in deinem Beruff" - to prefer Beruf to Stand (estate). Luther's concept of vocation, as Tom Brady has reminded us, is part of a much older tradition stretching back at least to the twelfth century, and forms part of his general teaching on estates, which he sees not as distinct and separate groups but as sets of relationships. Inasmuch as we are all bound to one another in social relationships, it is wrong to discern in Beruf the assertion of individualism, of the autonomous personality: Beruf, too, is a social relationship ${ }^{16}$.

Luther's views on trade and interest-taking are admittedly more substantial. The question is whether they represent anything more than the conventional wisdom of the age, or whether they offer, however tentatively, new and independent insights into the workings of money and commerce. When Luther turns, at the end of his Address to the Christian Nobility of the German Nation, to secular affairs - a passage of no more than a few pages - he makes it clear that his concern is to highlight the harmful social consequences of the practices which he condemns, rather than to investigate the processes which underlie those practices. Strictures

15 Justus Maurer, Prediger im Bauernkrieg (Calwer Theologische Monographien 5, Stuttgart 1979) 73 f., 437 f.; Hermann Barge, Jakob Strauss, ein Kämpfer für das Evangelium in Tirol, Thüringen und Süddeutschland (Schriften des Vereins für Reformationsgeschichte 54/2 [No. 162], Leipzig 1937) 61-79, esp. 63.

16 Brady, Luther and the State $35 \mathrm{f}$. 
against monopolies, for instance, are embedded in a general critique of luxury: the large trading companies import spices, silks, velvets and articles of gold into Germany, all extravagances which the common man can well do without. Luther regards this conspicuous consumption as breaking the bounds of the social order; his remarks follow directly upon his strictures on the expensiveness of clothing and transgression of the sumptuary laws ${ }^{17}$. He is not concerned to advocate a particular economic remedy, be it protectionism or autarky, a point to which I will return.

Luther's views on interest-taking, in the form of the purchase of annuities, it has often been observed, remain well behind contemporary Catholic opinion. Popes in the fifteenth century had already sanctioned the sale of annuities as compatible with canon law, and in 1515 Johann Eck, subsequently Luther's fiercest antagonist, had defended the taking of interest at five per cent at a public disputation in Bologna, and the following year the Fifth Lateran Council gave its approval to the montes pietatis, the low-interest-charging public pawnshops championed by the Franciscans as a means of protecting the poor against truly usurious moneylenders ${ }^{18}$. Luther agreed with the canonical prohibition on usury, conceding only that an interest-rate of between four and six per cent was permissable in certain circumstances, but that rates in excess of seven per cent were quite unjustifiable ${ }^{19}$. Behind this conventional view, however, lay startling insights into the nature of money and of accumulation, which will be examined in due course.

Yet the driving force of Luther's social and economic thought, I believe, lay elsewhere: in the responsibilities of the worldly magistrate. I am not concerned to resurrect ancient arguments over Luther and the state. Suffice it to say that Luther thought small, in terms of the household, the urban commune, and above all the patriarchal order of small territories ${ }^{20}$. The state as an impersonal and oppressive juggernaut would have been inconceivable to him. For Luther, rulership, authority, governance were vested in persons, not institutions, to whom fit and proper persons - councillors, jurists, and not least theologians - could and should offer advice if called upon. If Luther felt himself accountable as a believer coram Deo, with equal justice one might say that he saw himself as a Christian in the world enjoined to advise and admonish coram principe.

The duties of the ruler in Luther's understanding are often presented as circumscribed and elementary: in Tom Brady's diction, to punish sins, to restrain the wicked, and to promote God's Word ${ }^{21}$. This, to borrow the language of twentiethcentury corporatism, is to regard the ruler's duties as subsisting entirely in the Webramt. But there was another, more positive aspect to his responsibilities, that

17 Luther's Works: American Edition [LW]. Ed. Jaroslav Pelikan, Helmut T. Lehmann, 55 vols. (St Louis, Philadelphia 1955-86) 44, 212-216.

$18 \mathrm{LW} \mathrm{45,} \mathrm{234,} 298$.

19 Ibid. 305.

20 Theodor Strobm, Luthers Wirtschafts- und Sozialethik, in: Helmar Junghans (ed.), Leben und Werk Martin Luthers von 1526 bis 1546, 2 vols. (Berlin 1983) 1, 213.

21 Brady, Luther and the State 34. 
residing in the Näbramt ${ }^{22}$. Although never set down by Luther in any systematic treatment, the duties of magistrates clearly involved an active concern to promote the temporal welfare of their subjects. In what did this welfare consist, and how was it best brought about?

The Nähramt for Luther covered the entire spectrum of economic and social life, from sumptuary laws and charitable provision, to the regulation of trade, credit and interest, and to the fixing of prices for essential commodities. Essentially, Luther believed that the authorities had a general duty to steer the economy in a way beneficial to their subjects and themselves. Accordingly, he affirmed 1. that the population of a territory be encouraged to be wealthy, so as to ensure the livelihood of its individual subjects and to provide the territory as a whole with a fiscal resource ${ }^{23} ; 2$. that the territory, for similar reasons, should be populous ${ }^{24} ; 3$. that the territory should live in peace, not simply as a Christian duty, but to allow its economy to flourish ${ }^{25}$. In principle, these maxims could be applied to more than one economic system. In practice, however, Luther's ideological framework is that of a society which elevated agriculture above handicrafts, and handicrafts above commerce and finance. Indeed, he posits a scale of honourability, with agriculture as blessed at one end and finance as accursed at the other ${ }^{26}$.

Luther sees agriculture as man's primary economic activity, because God created nature first, the natural resources for man to exploit. Moreover, agriculture demands great physical effort; it engages the whole body and by so doing helps protect against the egotistic pursuit of profit ${ }^{27}$. In his own territory, Saxony, Luther was quite explicit: when he praised agriculture he meant tillage, the cultivation of grain, for bread is the staff of life. He argued consequently that the extensive cultivation of woad around Erfurt as an industrial crop should be discouraged precisely because it exhausted the soil and conduced to the acquisition of money - it made the peasant hungry for thalers, as he put it -, rather than satisfying immediate subsistence ${ }^{28}$.

All this might seem to confirm the image of a simple rural arcadia, were we not aware of the positive responsibilities implied in the Nähramt. Yet on closer in-

22 These are the terms used by Fabiunke, Luther als Nationalökonom $87 \mathrm{ff}$., but their implications are accepted by non-Marxist scholars, too. Cf. Ernst Eduard Albert Hahn, Die Bedeutung des Luthertums für die Entwicklung der Grundlagen der kameralistischen Wirtschaftslehre (Diss. jur.-pol. Göttingen 1942) 103-105. Luther's view of the prince's duty of care for his subjects was developed more fully by Melanchthon, who regarded happiness, following Aristotle, as the aim of human society. Cf. Georg-Christoph von Unruh, Polizei, Polizeiwissenschaft und Kameralistik, in: Kurt G. A. Jeserich, Hans Pohl, Georg-Christoph von Unrub (eds.), Deutsche Verwaltungsgeschichte, vol. 1 (Stuttgart 1983) 398.

${ }^{23}$ Sermons Expounding Matthew 18-24 (1537-40), Ch. 19. D. Martin Luthers Werke. Kritische Gesamtausgabe [WA], 67 vols. (Weimar 1883-1997) 47, 356.

24 Exposition of Psalm 147 (1532). WA 31/1, 437.

25 Ibid. 439.

26 Cf. Strabm, Luthers Wirtschafts- und Sozialethik $210 \mathrm{f}$.

27 T'R 3, 45, No. 2871b; cf. LW 44, 216; Fabiunke, Luther als Nationalökonom $102 \mathrm{f}$.

28 Ibid. 103; TR 3, 45, (No. 2871b); cf. TR 4, 177, (No. 4170); ibid. 305, (No. 4420). 
spection two aspects of Luther's view of nature and of the sanctity of manual labour point in quite unexpected directions.

In the first place, as the most natural and hence most godly labour Luther praises not simply agriculture but also mining. Although understandable in the light of his father's career, mining with its capital investment, division of labour, technological advances and break-down of production into separate and specialized stages might appear to fly in the face of Luther's critique of commercialized rural activity. But in his Exposition of the 127th Psalm to the Christians at Riga in Livonia (1524) Luther asks rhetorically: „Who puts silver and gold in the mountains so that man might find them there... Does the labor of man do this? To be sure, labor no doubt finds it, but God has first to bestow it..."29 They are as much a blessing of nature, of God's endowment, as the fruit of the field. Since he knew what mining involved, was Luther here tacitly and complicity sanctioning capital accumulation, specialization of production, and bullionism? After all, as Volker Press once observed, for all his polemic against south German capitalists and monopolists such as the Fuggers, Luther never offered any criticism of the Saxon mining entrepreneurs of his day, many of whom were known to him ${ }^{30}$.

The answer seems to be that Luther, who recognized the reality of the risks undergone by those who engaged in trade and industry, regarded mining as the risk venture par excellence. Riches, he said, are not in themselves contemptible, if they are the result of honest toil, rather than the riskless and indolent accumulation of money as interest. Whether labour in mining leads to wealth lies in God's hand. As he commented in his Exposition of the 6th Chapter of St Matthew's Gospel (1532) at verse 34 ("Take therefore no thought for the morrow; for the morrow shall take thought for the things of itself“): "Sihe wie es gehet auff den Bergkwerken, da man ia vleissig grebt und suchet, noch kompts offt also, das wo man am meisten ertz hoffet und sich beweiset, als wolts eitel gold werden, da findet sich nichts odder schneit sich bald abe und verschwindet unter den henden. "31 As Hermann Barge correctly remarked, this amounts almost to a wheel of fortune; it is not so much honest toil as mere chance which makes the yield from mining unobjectionable: „Summa es sol heissen nicht gesucht sondern beschert, nicht gefunden sondern zugefallen, wenn glueck und segen dabey sein sol.“"32

In the second place, although Luther emphasized that the primary purpose of the production of goods was consumption, and that their exchange-value was secondary, none the less he realized that in society as it was constituted buying and selling were inevitable, and that commerce to supply essential commodities was legitimate. From the perspective of the Näbramt it was incumbent upon the magistrate to ensure that commercial exchange did not lead to distortions of price

${ }^{29}$ LW 45, 327; Strohm, Luthers Wirtschafts- und Sozialethik 210.

30 Volker Press, Martin Luther und die sozialen Kräfte seiner Zeit, in: idem, Ausgewählte Aufsätze. Ed. Johannes Kunisch (Historische Forschungen 59, Berlin 1997) 600.

31 WA $32,471$.

32 Ibid. Hermann Barge, Luther und der Frühkapitalismus (Schriften des Vereins für Reformationsgeschichte 58/1 [No. 168], Gütersloh 1951) 32. 
and supply; to that end Luther suggested that the price of goods be fixed by tariff and that the number of merchants should be limited ${ }^{33}$.

By conceding this point, Luther was obliged to recognize the necessity and indeed the utility of the division of labour by which goods destined for exchange, that is, commodities, were produced. Moreover, he was bound to acknowledge that the price of those commodities was not determined in the first instance by any intrinsic or fixed value in the money used to exchange them - the bullionist assumption - but by the labour required to produce them ${ }^{34}$. In effect, labour itself becomes a commodity. Luther, of course, never thought that far. A reified concept of labour based on objective criteria - labour-input, labour-time - fundamental to classical economics would have been repugnant to a man who saw work as service to one's neighbour ${ }^{35}$.

Nevertheless, the existence of a commercial economy based on the division of labour and the exchange of commodities encouraged Luther to reflect on the nature of money. In his arguments on interest-payments he examines the circumstances which might justify the taking of interest; clearly they had to involve an element of risk. Loans without risk were usury pure and simple. That is why he distinguished sharply between capital invested in a business, which by definition involved risk, and the buying of annuities with a guaranteed income, which involved no risk at all, and hence was objectionable ${ }^{36}$. Nevertheless, in On Trade and Usury and again in To the Parish Clergy, to Preach against Usury Luther advances the principle of interest-payments as compensation for arrears or default on the money lent, what he calls Schadewacht. The risk involved was both that of a real or actual loss and a loss arising through foregone profit (that is, money which might otherwise have been profitably invested elsewhere for the duration of the loan). This distinction between loss as titulus damni emergenti and loss as titulus lucri cessantis shows Luther fully aware that money possessed an intrinsic capacity to accumulate - that it could provide both consumption credit and productive credit -, in other words that money possessed the property of capital ${ }^{37}$.

This is a view which a minority of scholastic thinkers, as Raymond de Roover has shown, had already advanced. Against the majority, who clung to the Aristotelian belief that money was sterile, some fourteenth-century moralists, such as Gregory of Rimini, Peter of Ancarano, and Lorenzo Ridolfi, had cautiously con-

${ }^{33} \mathrm{LW} 45,249$; Fabiunke, Luther als Nationalökonom $113 \mathrm{ff}$.

34 Ibid. 99. Cf. Hermann Lebmann, Luthers Platz in der Geschichte der politischen Ökonomie, in: Günter Vogler (ed.), Martin Luther. Leben - Werk - Wirkung (Berlin 1983) 283.

35 Strobm, Luthers Wirtschafts- und Sozialethik 210.

${ }^{36} \mathrm{LW} 45,300$.

37 WA 51, 344f; Fabiunke, Luther als Nationalökonom 130-131; Hans-Jürgen Prien, Luthers Wirtschaftsethik (Göttingen 1992) 137f. Prien questions Fabiunkes's view that Luther thereby recognized the inherent capacity of money to accumulate, for he speaks in the context of a largely agrarian economy, where only grains had any natural capacity to reproduce themselves severalfold. But this ignores Luther's view on mining and on his contacts with the Mansfeld mineworkers (to which Prien devotes culpably little attention). 
ceded that compensation was allowable on loans made from necessity or charity 38 . But a century earlier, the French Spiritual Franciscan, Peter Olivi, had extended the remit of lucrum cessans to cover any loan where a ,probable profit', calculated as an average rate of return over time, had been foregone ${ }^{39}$. Money as something seminal rather than sterile, which as capital invested in a business venture would produce a legitimate profit, was a concept with which the scholastics struggled San Bernardino contradicted himself on the issue -, but they had certainly pioneered a new understanding of money and interest well before Luther ${ }^{40}$.

Nevertheless, there is no indication whatever that Luther arrived at his views through a reading of the scholastics, of whose theology in any case he was mostly so contemptuous. He appears to have come to his understanding independently; it cannot be ruled out that his knowledge of the mining industry led him to these insights. Despite the need to tread warily, some historians and economists, particularly certain Marxists, have not shrunk from reaching highly incautious conclusions about the originality of Luther's thought. Yet Marx himself argued only that Luther recognized both the necessity of commerce and the nature of goods as commodities, as well as the different properties inhering in money as a means of purchase and as an instrument of accumulation. He did not argue that Luther was the direct pioneer of the labour theory of value, an accolade which he reserved for the true founder of political economy in his eyes, the English seventeenth-century statistician and agrarian reformer, Sir William Petty ${ }^{41}$.

\section{III.}

Michael Gaismair's Territorial Constitution for Tirol has received as contradictory and inconsistent interpretations as Luther's writings on social and economic issues $^{42}$. It is frequently seen as a Utopian blueprint, estranged from reality, pro-

38 Raymond de Roover, San Bernardino of Siena and Sant'Antonio of Florence: The Two Great Economic Thinkers of the Middle Ages (Boston 1967) 31.

39 Julius Kirshner, Raymond de Roover on Scholastic Economic Thought, in: de Roover, Business, Banking and Economic Thought 30.

40 Idem, Scholastic Economics. Survival and Lasting Influence from the Sixteenth Century to Adam Smith, in: ibid. 310.

41 Karl Marx, Theories of Surplus Value, vol. 1 (London 1967) 1.

42 The main interpretations are reviewed in Politi, I sette sigilli, part 1, 12-38. To these should be added Ganseuer, Staat des "gemeinen Mannes“ 187-235. Text (in English translation) in: Tom Scott, Bob Scribner (eds.), The German Peasants' War: A History in Documents (Atlantic Highlands, NJ, London 1991) 265-269; German texts (with exhaustive philological and diplomatic analysis) in Giorgio Politi, I sette sigilli della "Landesordnung “. 2. Per una restituzione del testo, in: Annali dell' Istituto storico italo-germanico in Trento 14 (1988) 87-232: Vienna text 208-215; Brixen/Bressanone text 223-231. Politi has meanwhile incorporated these findings into a book, which contains an added section devoted to Gaismair's career before and after his exile. Giorgio Politi, Gli statuti impossibili. La rivoluzione tirolese del 1525 e il „programma" di Michael Gaismair (Turin 1995). It also corrects some slips in his previous 
jecting social and economic relations back in time to an age of innocence, ignorant of or hostile towards trade, enterprise and capital accumulation. In so far as commercial activity was to be tolerated, the Constitution provided that it should be under state control, in public ownership, and directed to the common good. These provisions were extended in particular to the Tirolean mining industry.

Gaismair's is not the only social and economic programme to have emerged in the early years of the Reformation. Given its genesis within the unfolding Peasants' War it most properly bears comparison with Friedrich Weygandt's draft of an imperial reform programme intended to be submitted to the Heilbronn ,peasants' parliament' of May 1525, which in turn was based upon the so-called Teutscher Nation Notturft of 1523 . These were only the latest in a long line of imperial reform proposals stretching back to the early fifteenth century. In its concern for the establishment of a sound coinage, uniform weights and measures, and restrictions upon the activities of the large monopolistic trading houses Gaismair's Constitution echoes for Tirol what Weygandt and others proposed for the Empire as a whole ${ }^{43}$. Their concerns were indeed the subject of repeated debate at imperial diets in the first half of the sixteenth century.

Within Tirol itself, many of the clauses of the Constitution take up and systematize long-standing grievances, such as those expressed in the Meran/Merano Articles submitted to the territorial diet in May 1525, in which Gaismair's hand has often been descried ${ }^{44}$. If the Constitution were no more than a redaction of earlier grievances, however, it would scarcely merit particular analysis here. Its continuing fascination lies in the fact that its detailed provisions are embedded in a wider view of the social order - in an ideological framework derived from reforming precepts, with which Gaismair became acquainted through his contacts with Zwingli in Zürich in the winter of 1525/26.

This is not the place to discuss the formidable source problems surrounding the Tirolean Constitution in any detail. All those who have analyzed the Territorial Constitution (the term Landesordnung is a gloss by a later hand) agree that it contains internal inconsistencies, repetitions, and linguistic oddities, so that it cannot represent a finished document. Most recently, however, in an exhaustive examination, Giorgio Politi has shown beyond peradventure that the Territorial Constitution - against the views of its previous modern editors, Albert Hollaender and Jürgen Bücking - cannot be either an autograph or even a fair copy of Gaismair's text. Rather

rappresenta insomma la Landesordnung non come la pensò il suo autore ma come reiusciron a ricostruirla (o come vollero anche ricostruirla) i suoi nemici, in base fosse a qualche frammento scritto, ma soppratutto, con ogni probabilità, ai rapporti delle spie e alle confessioni dei congiurati ${ }^{45}$.

edition of the texts. Cf. the review by Aldo Stella in: Rivista di storia della Chiesa in Italia 49 (1995) 533-538.

43 Scott, Scribner, German Peasants' War 259-264.

44 Ibid. 86-91.

45 Politi, I sette sigilli, part 1, 59. 
This textual farrago Politi contrasts unfavourably with the clear focus of earlier articles of grievance emanating from the South Tirolean rebels. Be that as it may, any attempt to detect a continuity or development between them is fraught with difficulty. Jürgen Bücking's suggestion that Gaismair's programme should be styled as his Second Territorial Constitution, elaborating ideas first adumbrated in the Neustift/Novacella Articles of 14 May 1525 or, in an abbreviated form, in the Articles of the Town of Brixen/Bressanone a week later, has encountered a very mixed response from scholars, though much of the debate concerns Bücking's unfortunate nomenclature, rather than the content of these sets of articles. In my view, although they undoubtedly contain elements which prefigure the Territorial Constitution, neither set of articles should be ascribed in any direct sense to Gaismair ${ }^{46}$. Even the Meran/Merano Articles, with a better claim to Gaismair's involvement, find far fewer echoes in the Constitution than is commonly supposed. Of the eleven (from a total of 62) Meran Articles which deal with economic and commercial matters, only four (though they include the mines) have corresponding provisions in the Territorial Constitution, though some other oblique connections can be made 47 .

The economic clauses of the Constitution may conveniently be considered under three headings: agriculture, artisan production, and mining.

1. Gaismair puts forward an ambitious, but in principle entirely feasible, plan to increase the agricultural output of the territory, which is intended to have the additional benefit of improving the population's health. Draining the marshes down the Etsch/Adige valley would not only bring more land into cultivation, chiefly as pasture, but remove the ,noxious vapours' emanating from them, that is, the danger of malaria. Although Gaismair is keen to promote the staples of meat and grain, he is just as concerned to encourage the planting of olive-trees and the improvement of viticulture ${ }^{48}$. Indeed, he expressly advocates a diversified agricultural regime modelled on the Italian commercialized system of cultura promiscua.

This work of improvement - reminiscent of some eighteenth-century agronomists - is to be carried out in each district by the entire community, organized in labour brigades, under communal supervision, every year at the appropriate time. This provision, with its overtones of the Chinese cultural revolution, should not be taken as the forerunner to the expropriation of tenant farms or the collectivization of agriculture. Gaismair says nothing directly about peasant proprietary

46 Bischoff-Urack, Gaismair $109 \mathrm{f}$. The Neustift Articles make no reference to mining, but they do mention the Fuggers as a trading company, while the Brixen Town Articles refer to the (monopolistic) merchant companies. Ibid. 117. Bücking's suggestion of a direct link between the Neustift articles and the Territorial Constitution is vigorously dismissed by Politi, Gli statuti impossibili 279-286, but regarded as plausible by Aldo Stella, Il „Bauernführer“ Michael Gaismair e l'utopia di un repubblicanesimo popolare (Annali dell'Istituto storico italo-germanico in Trento, Monografie 33, Bologna 1999) 99-104.

47 Meran Articles $\$ \$ 18,21,22,32$. Scott, Scribner, German Peasants' War $90 f$.

48 Cf. Jürgen Bücking, Michael Gaismair: Reformer - Sozialrebell - Revolutionär. Seine Rolle im Tiroler „Bauernkrieg“ (1525/32) (Spätmittelalter und Frühe Neuzeit. Tübinger Beiträge zur Geschichtsforschung 5, Stuttgart 1978) $158 \mathrm{nn} .66,67,69$. 
rights, but we are justified in inferring that individual/family ownership of land within the framework of communal jurisdictions would continue. The provision that there should be no commerce in land can perhaps be seen as reinforcing this, inasmuch as it seems intended to prevent the accumulation of large landholdings by graziers and the spread of commercial leases ${ }^{49}$.

2. Elements of state supervision and nationalization, by contrast, are readily visible in the clauses dealing with crafts, manufacturing and distribution. Gaismair envisages two markets for his territory, centrally located in the Etsch/Adige valley for South Tirol and in the Inn valley for North Tirol. There all manufactured goods are to be sold, with the hawking of goods by itinerant pedlars (a standard grievance of the day) banned. In the same spirit Gaismair proposes Trent as the territory's central - and sole - manufactory, where all artisan and industrial production shall take place under a publicly appointed superintendent on a state salary ${ }^{50}$. Consequent upon this centralization, all internal tolls are to be abolished; only at the frontier of the territory are tolls to be levied on exports, while imports go toll-free ${ }^{51}$.

To see in these plans a recipe for autarky and a subsistence economy is to go too far, however. Gaismair recognizes that one central manufactory and two regional markets may be insufficient to ensure the efficient distribution of goods in an economy where commodity exchange is fundamental, since he allows for additional shops to be set up if necessary 52 . Diversified agriculture, particularly grazing and viticulture, is not part of a subsistence regime. And the manufactures to be located in Trent include items - silks, hats, brassware, velvets, shoes - some of which must be regarded as luxuries. Moreover, while Gaismair is keen to restrict exports across the Confinen of Tirol, here understood expressly as the southern frontier into Italy, he envisages importing what the land itself cannot provide, in the first instance spices ${ }^{53}$. In these respects Gaismair goes well beyond Luther.

An anti-commercial stance has sometimes been deduced from remarks earlier in the Constitution about towns, which in his view should be abolished. This reading is not sustainable. The passage in question addresses the issue of fortified places in general - castles as well as circumvallated towns. These strongholds are to be eliminated in order to ensure social equality in the territory or, to put it another way, to make certain that such fortified places cannot defy the common will by insisting upon their liberties, their immunities, in hiding behind high walls. The provision has nothing whatever to do with economic activity in the towns - the dubious practices of merchants, the enforcement of staples, price-rigging, and the privileges of the craft guilds. This impression has arisen because the Meran Articles do identify such abuses, and it is assumed that they must have been carried over into the Territorial Constitution (which says next to nothing on such

${ }^{49}$ Territorial Constitution $\$ 19$. Scott, Scribner, German Peasants' War 267.

$50 \$ \$ 19,22$. Ibid. 268.

$51 \$ 15$. Ibid. 266.

$52 \$ 19$. Ibid. 268.

$53 \$ 19$. Ibid. 268. 
matters $)^{54}$. Rather, Gaismair's purpose is explicitly egalitarian: to create a Christian Commonwealth in which there shall be no distinction between men.

In so far as a particular economic stance can be inferred from Gaismair's comments on the circulation of goods and money, then he is a declared monetarist or bullionist. Over and over again he is concerned to preserve coin or bullion in the land, to establish a sound domestic coinage, and to reject foreign specie unless it is of equivalent weight and fineness. Adequate reserves of bullion are necessary, moreover, in case of military emergency 55 .

3. This bullionist stance was clearly informed by Gaismair's own experience of mining in Tirol, and it is the concluding section on mining in the Tirolean Constitution which has attracted the greatest attention. In it, Gaismair's hostility towards the foreign mining companies, especially the South German merchant houses of the Fugger, Höchstetter, Baumgartner and Bimmel, is manifest. He accuses them of usury (which we may translate here as making excessive profits), of paying their workers in truck, and of driving up the price of basic commodities by forestalling. Consequently, Gaismair calls for the nationalization of all mines and smelteries owned by the nobility and foreign merchants. Smelting, indeed, is to be run as a state collective enterprise under an inspector-general, with the price of ore determined by a state tariff, not by market forces ${ }^{56}$.

The detail and emotion with which Gaismair comments on the Tirolean mining industry certainly reflect his own knowledge and experience, but do so from a quite particular angle, that of his own family's business history. For one thing, his call for the expropriation of noble mine-owners does not seem to have much connection with the activity of the foreign monopolistic merchant houses. It is only intelligible against the background of attempts by Gaismair's father, Hans, to obtain a lease on the smeltery in Sterzing from Emperor Maximilian in 1507. When the monarch refused, the Gaismairs switched their attention to Persen/Pergine by Trent. Here they established a haulage company and business firm with investments in the local mines, but were thwarted in their ambitions by the local aristocratic family of Trautmannsdorf, which ran up considerable debts with the Gaismairs which were never discharged. Persen was abandoned after 1516 in favour of investment in Ladurnsbach by Sterzing 57 .

For another, Gaismair's remarks on the predicament of the lesser mining shareholders who were not themselves smelting-masters not only reflected his own family's situation as small investors in general but the particular circumstances of the industry round Sterzing. After 1500 mine- and smeltery-owners from Schwaz

$54 \$$ 5. Ibid. 266. Cf. Meran Articles, $\$ \$ 20,27,28,47$. Ibid. 90, 91, 93. Cf. Siegfried Hoyer, Die Tiroler Landesordnung des Michael Gaismair. Überlieferung und zeitgenössische Einflüsse, in: Fridolin Dörrer (ed.), Die Bauernkriege und Michael Gaismair. Protokoll des internationalen Symposions vom 15. bis 19. November in Innsbruck-Vill (Veröffentlichungen des Tiroler Landesarchivs 2, Innsbruck 1982) 72.

55 Territorial Constitution $\$ \$ 20$, 22. Scott, Scribner, German Peasants' War 268.

56 Ibid. $268 \mathrm{f}$.

57 Bischoff-Urack, Gaismair 47-51. 
began to encroach upon the Sterzing industry to the point where it threatened to decline to the status of a dependent supplier under the control of a vertically integrated monopoly-capital business, in which Schwaz entrepreneurs co-ordinated extraction, smelting, transport, as well as the marketing of the refined silver ${ }^{58}$.

Gaismair's response was to nationalize the mines, but that policy was not altogether what it seemed, and certainly did not imply the socialization of the mining industry as a whole ${ }^{59}$. His plans ignored the substantial mining investments of native Tirolean entrepreneurs, such as the Stöckl, Fieger, and Tänzl in Sterzing itself, whose businesses remained untouched by his proposals ${ }^{60}$. Gaismair's plans also envisaged the continuation of wage-labour in the mines and the existence of small-scale mining shareholders ${ }^{61}$.

Gaismair sees the future prosperity of Tirol as depending directly upon the yield of its silver-, lead-, and copper-mines. He even hopes that mining revenue will be sufficient to cover all ordinary public expenditure, so that no taxes need be levied. He is particularly anxious, therefore, to promote further mining exploration - and nowhere does he suggest that prospecting be restricted to state enterprises. The entire thrust of the mining chapter of the Tirolean Constitution is to safeguard the position of the labour-employing petty-capitalist mining shareholders against the threat of subordination to the oligopolists of the South German cities.

It is necessary to add that this interpretation is fundamentally at odds with that of Politi, who dismisses any concern by Gaismair to protect the interests of his social class, and who regards the mining article by virtue of its diction and language as largely inauthentic. But his approach is grounded exclusively in a highly rigorous textual analysis, which is not only indifferent to the wider ideological-material context of Gaismair's vision, but which rejects out-of-hand the one attempt - by Angelika Bischoff-Urack - to test Gaismair's proposals against the real-historical background of his and his family's career ${ }^{62}$.

58 Ibid. 33.

59 Politi is scathing about this proposal, blindly swallowed by all previous scholars. How could the mines be ,nationalized" when, as regalian rights, they already belonged to the prince (archduke Ferdinand of Austria), who had merely leased them to mining entrepreneurs? Politi, I sette sigilli, part 2, $93 \mathrm{f}$.; idem, Gli statuti impossibili $98 \mathrm{f}$. His objection is fatuous: the mines were to be taken out of feudal ownership and entrusted to the commonwealth.

60 Bischoff-Urack, Gaismair 29.

61 Karl-Heinz Ludwig, Zur Interpretation „Des Pergwerchs“ in der „Landesordnung“ des Michael Gaismair von Anfang 1526, in: Technikgeschichte 44 (1977) 45; idem, Sozialemanzipatorische, politische und religiöse Bewegungen 1524-1526 im Montanwesen des Ostalpenraums, in: Dörrer, Die Bauernkriege $213 \mathrm{f}$. Bischoff-Urack points out that Gaismair had already been the co-signatory of gravamina sent in 1512 (or earlier) to emperor Maximilian on behalf of the "common association in Falkenstein and Weißenschrofen ", which voiced the concerns of small shareholders (Gewerken), contract labourers (Lebenhäuer), and wage-labourers at the practices of the large mining shareholders and the mining judge (as the prince's agent). Bischoff-Urack, Gaismair $68 \mathrm{f}$.

62 In a complete caricature he accuses Bischoff-Urack of portraying Gaismair as a 16th-cen- 
An initial comparison of Luther and Gaismair reveals more congruences than one might suspect.

1. Although both men are opposed to the large-scale enterprises and monopolies of their day, neither draws the conclusion that commerce as such can or should be prohibited.

2. Their shared concern to prevent usury places severe restrictions on the development of credit and investment, but does not rule out a concern for sound money or the recognition of money's necessary role as a medium of exchange.

3. Their admiration for an agrarian society cannot be equated with simple subsistence husbandry, since both men stress the importance of natural resources, which include precious metals, whose extraction and processing required investment and technology beyond anything conceivable within a subsistence economy.

4. The rights of private property are respected by both men. Luther justifies the private ownership of the means of production by pointing to the necessity of the Christian possessing the wherewithal to help his neighbour. Just as human labour, so too property serves a social function and should be used ethically not egotistically. Gaismair seeks to balance the interests of equality and the Christian commonweal, which in his vision require state ownership and control of some branches of the economy, against peasant proprietorship of the family farms and the stake of shareholders in the mines, where dependent wage-labour will continue to be employed.

5. It is the function of the Obrigkeit, whether it be the prince, the civic magistrate, or the communally controlled territory, to promote the welfare of the population by active means. That includes wealth-creation, both individually and collectively within an economic system which allows and encourages the economic initiative of the individual, but whose inherent dangers make extensive regulation and control necessary ${ }^{63}$.

That is not to elide or obscure the differences between Luther and Gaismair, some of which were obviously predicated upon their personal situation and profession. Luther, the conservative (and the eschatologist), was suspicious of all those who believed that the world could be made fully conformable to God's will

tury yuppie, and ignores her attempts (which continue the researches of Karl-Heinz Ludwig) to reconstruct Gaismair's career. Politi, I sette sigilli, part 1,29. This contempt has been toned down in Politi, Gli statuti impossibili 26, where her depiction of Gaismair becomes merely „una sorta d'arrivista“. Politi's criticism of Bischoff-Urack's textual expertise should be set against Stella's review of Politi's own shortcomings in: Rivista di storia della Chiesa in Italia 49 (1959) 533-538.

63 For Luther cf. WA 31/1, 439: „es ligt der Oberckeit viel dran, das sie reiche unterthan hab, und sie selbst auch reich sei. Den ohn gelt und guth kann widder das weltlich regiment noch einige Haushaltung bestehen." The positive function of the Obrigkeit is also recognized by Prien, Luthers Wirtschaftsethik $161 \mathrm{f}$., who speaks not of a Näbramt but of a Nächstenamt. Ibid. $158,229 f$. 
(he had, after all, first-hand experience of Thomas Müntzer). Gaismair, the radical and activist, was inspired by his contacts with the Zürich Reformation to put forward the vision of a new Christian republic in South Tirol. His Territorial Constitution betrays obvious affinities with Zwingli's Radtschlag as a plan of campaign in defence of the Word of God, including the establishment of an independent government (or republic) in the Etsch valley, which Politi has plausibly suggested was intended to comprehend the secular territories of the bishops of Brixen and Trent, the core of ,Gaismair's land', as it is described in the Territorial Constitution $^{64}$. Whether the Tirolean Constitution as a whole flew in the face of reality need not concern us here, except to caution that the negative judgement passed specifically on its economic provisions by Jürgen Bücking is altogether too facile 65 .

\section{V.}

Among the Reformers of the sixteenth century Luther and Gaismair stand out as thinkers who identified the economic problems of their day and sought to offer solutions which they believed were consonant with the teachings of the Gospels. It is significant, therefore, that neither man chose to embrace simple self-sufficiency (let alone apostolic poverty), or to reject private property. Despite their commitment to a Christian commonweal, neither was the advocate of a classless society.

Yet how their economic thinking should be characterized, and how it should be categorized within the evolution of political economy are questions which remain highly controversial. Within the Marxist tradition, the necessity to demonstrate that Karl Marx never erred has proved particularly fateful. In the German Democratic Republic, the thesis of the early bourgeois revolution, propounded in the early 1960s, posited a direct ideological lineage from Luther to Adam Smith (described, alas, by Engels as ,the economic Luther'), and essentially bracketed the evolution of political economy in the intervening centuries. Not only did this orthodoxy ignore Marx's own reflections in the Grundrisse on mercantilists, cameralists, and physiocrats, it also consigned to obscurity the one East German work which does build upon Marx's insights and which does discuss (in passing) mer-

${ }^{64}$ Politi, I sette sigilli, part 1, 64f., 74, 79ff., 85. Politi merely follows the modern consensus that the Radtschlag should be dated to early 1526 , rather than late 1524 /early 1525 , as its editors had supposed. Cf. Otto P. Clavedetscher, Die Bauernunruhen im Gebiet der heutigen Eidgenossenschaft. Mit einem Exkurs über die Beziehungen Gaismairs zur Schweiz, in: Dörrer, Die Bauernkriege 153-160, here at 158. Text of the Radtschlag in: Huldreich Zwinglis Sämtliche Werke, vol. 3. Ed. Emil Egli, Georg Finsler, Waltber Köbler (Corpus Reformatorum 90, Leipzig 1914) 551-583; plans for Tirol, 563. Stella, Il „Bauernführer“ 133-139 concurs with the modern dating, but does not discuss whether the plan was primarily directed at the ecclesiastical principalities.

65 Bücking, Gaismair $89 \mathrm{f}$. 
cantilists and cameralists as the pioneers of modern political economy, namely Günter Fabiunke's Martin Lutber als Nationalökonom (1963). Not that Fabiunke himself can be absolved from passing apodictic judgements - for instance, that Luther's thought is an amalgam of feudal, peasant-proprietorial, and petty-bourgeois elements ${ }^{66}$. It is not that such judgements are necessarily wrong; rather, they create a false impression. Luther, it seems, is consigned to an intellectual playpen, in which he naively seeks to reconcile the irreconcilable, so that his thought remains syncretic, macaronic, or simply incoherent. In recent times - though not by Marxist historians - similar charges have been laid against Gaismair, whose Tirolean Constitution is supposed to contain both petty-capitalist and socialist elements in uneasy juxtaposition. Jürgen Bücking has arraigned the Tirolean Constitution as a whole on the grounds of primitivism, xenophobia, ethnocentrism, moral rigorism, anticapitalism, rational-bureaucratic planning, and a belief in the cyclical nature of social processes - in short, he denounces Gaismair's ideal Tirol as a Hegungsstaat, a term coined as recently as 1967 by R. F. Behrendt, and which could somewhat loosely be translated into English as the nanny state ${ }^{67}$. It is difficult to suppress the feeling that such verdicts tell us more about their authors and their authors' agendas - than they do about Luther or Gaismair. That is not to deny the contradictory or incompatible elements in both men's thought. Rather, it is to suggest that their fractured thinking may mirror a fractured reality, confronted as they were with a society - in Saxony and the Tirol, at least - which displayed all the symptoms of die Gleichzeitigkeit des Ungleichzeitigen.

\section{VI.}

The sixteenth century in Germany was the first great age of Polizey (good police), when the authorities began to intervene in social and economic affairs for more than merely fiscal or defensive purposes. The aspect of Polizey which has received most attention is that which is now called social disciplining, but intervention in or regulation of economic and commercial life was of equal importance. The motives were both positive and negative: to augment princely revenues in the face of mounting civil and military expenditure, but also to inhibit practices which were held inimical to the commonweal. It used to be thought that Polizey was chiefly the preoccupation of the territorial princes, but since the researches of Fritz Blaich it has become clear that the imperial diet returned continually throughout the sixteenth century to economic and commercial questions: the harmful consequences of monopolistic enterprises, the need to stem the loss of bullion from Germany and to promote domestic industries (such as the manufacture of woollen cloth), as well as the regulation of coinage (at last crowned with success in 1559 in the im-

66 Fabiunke, Luther als Nationalökonom 144.

67 Bücking, Gaismair 90. 
perial coinage ordinance) ${ }^{68}$. These concerns took on a new urgency after the catastrophe of the Thirty Years War, when one of the main issues became the repopulation of territories which had suffered severe demographic haemorrhaging. Princely councillors, jurists, and theologians were not slow to offer advice; over time a body of applied learning developed known as cameralism, the specifically German variant of the wider economic doctrines loosely subsumed under the term mercantilism. Fundamental to these doctrines were three questions:

1. How to identify the sources of wealth within society;

2. How to harness that wealth in the most productive way;

3. How to determine the role of the state in promoting the wealth of its citizens.

Underlying these questions was the assumption that economics has its own set of principles or laws, which allow predictions to be made, so that economic life is not simply governed by chance or fate.

Definitions of mercantilism are as many as its manifestations. Raymond de Roover was surely right to remark that "mercantilism was never more than a conglomerate of unco-ordinated prescriptions ${ }^{\text {"69. }}$. Yet the essence of mercantilism can be summed up in two words: bullionism and autarky. The state's requirement for greater resources was seen to be satisfied principally in the accumulation of reserves of precious metals, either as bullion or as struck coin. As a result, customs policy became of paramount importance. Imports, which might constitute a danger to the state's balance of payments, were to be restricted, while simultaneously a positive balance of trade was to be achieved through the promotion of exports. Ultimately such a policy could only succeed by beggar-my-neighbour, by damaging the economy of other countries while protecting one's own. The promotion of the domestic economy became, therefore, a chief aim, in order to produce goods for export; by the eighteenth century manufactories turning out luxury or high-value commodities had been set up in many territories, though state industries usually occurred at a later stage in mercantilist politics than the autarkic promotion of agriculture. Underpinning these policies was the fundamental recognition of the link between the circulation of money and the level of employment ${ }^{70}$.

In the German context these goals were linked to policies which elevated the ruler to a supreme position, underscored by lavish buildings, ceremonies and representation. The power of the quasi-absolutist ruler was buttressed by a standing army, while the civil administration was expanded to reach down to the most local

${ }^{68}$ Fritz Blaich, Die Reichsmonopolgesetzgebung im Zeitalter Karls V. Ihre ordnungspolitische Problematik (Schriften zum Vergleich von Wirtschaftsordnungen 8, Stuttgart 1967); idem, Die Wirtschaftspolitik des Reichstags im Heiligen Römischen Reich. Ein Beitrag zur Problemgeschichte wirtschaftlichen Gestaltens (Schriften zum Vergleich von Wirtschaftsordnungen 16, Stuttgart 1970).

69 de Roover, Scholastic Economic Thought 322.

70 Walter Achilles, Landwirtschaft in der frühen Neuzeit (Enzyklopädie Deutscher Geschichte 10, Munich 1991) 10 ff.; Rainer Gömmel, Die Entwicklung der Wirtschaft im Zeitalter des Merkantilismus (Enzyklopädie Deutscher Geschichte 46, Munich 1998) $41 \mathrm{f}$. 
level, with a particular concern for fiscal policies and the maximization of state revenues. After the Thirty Years War repopulation policy, including the encouragement of immigrants (often religious refugees) with particular skills became another principal strand of cameralism ${ }^{71}$.

Apart from Peuplierungspolitik, however, the specifically mercantilist components of cameralism were all foreshadowed in the sixteenth century in Germany (as many of the debates of the imperial diet make plain), even if a systematic doctrine of mercantilism was not elaborated until the Politischer Diskurs of Johann Joachim Becher in the second half of the seventeenth century. Indeed, much $P_{o-}$ lizey legislation is simply a rehearsal for fully-fledged mercantilist policies later on. The first German territory fully to embrace mercantilism as its declared policy is usually taken to be Hessen under the rule of landgrave William IV (1567-92) ${ }^{72}$, though examples of cameralist thought can be found elsewhere, for instance in the policy guidelines accompanying the establishment of a treasury for Outer Austria in $1570^{73}$.

That there are evident parallels between the thinking of Luther and Gaismair and the later mercantilists or cameralists has not gone entirely unnoticed in the historical literature, thought they have been overshadowed, in the case of Luther, by strident attempts to demonstrate his direct legacy to classical political economy. The links between the Reformation and cameralism in Lutheran principalities have been explored in a study of the leading cameralist of the late eighteenth century, Johann Heinrich von Justi. Luther would not have argued, as von Justi did, that his task was to indicate how the ,power and happiness' of state might best be increased, but Luther's teaching on the Näbramt finds a distinct echo in von Justi, even if the latter only cited Luther once ${ }^{74}$. Von Justi's debt to Luther is, in fact, an indirect one, running via the seventeenth-century writer Johann Gerhard (d. 1637), one of the first Lutheran theologians not to regard interest-taking per se as usury ${ }^{75}$.

Luther's dictum, "Geld haben, erwerben, trachten nach der Nahrung non est malum "76, could have been adopted by von Justi as his maxim without difficulty.

${ }^{71}$ Friedrich-Wilhelm Henning, Das vorindustrielle Deutschland 800 bis 1800 (Paderborn, Munich, Vienna, Zürich $\left.{ }^{4} 1985\right)$ 239-243.

72 Strobm, Luthers Wirtschafts- und Sozialethik 213. Strohm insists that Luther knew nothing of mercantilism, but this is to fall foul of a descriptive insistence on the formal recognition of categories.

${ }^{73}$ Karl Josef Seidel, Das Oberelsaß vor dem Übergang an Frankreich. Landesherrschaft, Landstände und fürstliche Verwaltung in Alt-Vorderösterreich (1602-1638) (Bonner Historische Forschungen 45, Bonn 1980) $141 \mathrm{ff}$. The example of Outer Austria shows that protocameralist thought was not confined to Protestant intellectuals or Protestant principalities. $74 \mathrm{Habn}$, Bedeutung 103, 109. Luther as an ancestor of cameralism is recognized by Fabiunke, Luther als Nationalökonom 160.

$75 \mathrm{Habn}$, Bedeutung 118, 147.

76 Sermons of 1528 , no. 71,20 Sept. 1528. WA 27,343 . The context, however, is an explicit rejection of mammon. 
In his criticism of a crude belief in bullionism and his sympathy for physiocratic doctrines, moreover, von Justi offers another echo of Luther. Rejecting the view that the wealth of a territory is measurable by the amount of gold and silver it possesses, von Justi sees that wealth arises from the surpluses provided either by the fertility of the soil or beneficence of the climate, or from the skill and labour of its inhabitants 77 .

It is important to stress these parallels, since they seem to contradict passages in Luther, most notably at the end of his Address to the Christian Nobility of the German Nation, where he appears to adopt a monetarist stance. The expenditure on foreign luxuries such as spices, which are both costly and unnecessary, sucks money out of Germany, he declares. In On Trade and Usury he warms to his theme: "God has cast us Germans off to such an extent that we have to fling our gold and silver into foreign lands and make the whole world rich, while we ourselves remain beggars." Frankfurt, he concludes, is the drain through which gold and silver flow out of Germany ${ }^{78}$. A mercantilist might well have said something similar, but, as I have already suggested, Luther's purpose was to highlight the socially harmful consequences of the loss of bullion; he was not concerned with the loss of a nation's treasury of wealth as such but with the general impoverishment which follows from it ${ }^{79}$. A lack of money in a commercialized economy is bound to restrict the circulation of goods; the exchange of necessary goods, Luther admits, is the lifeblood of the economy. Von Justi, who shared Luther's instinctive view that money in itself was sterile, said exactly the same thing ${ }^{80}$.

Although Luther places the highest value on agriculture, there are difficulties in linking him too directly to the physiocrats. Luther, as we have seen, is indifferent towards agricultural improvements and positively hostile towards diversification into industrial crops, and therefore hardly qualifies as a obvious precursor of François Quesnay. What he does recognize, as did the physiocrats, is that the material basis of wealth is vested in land and the produce thereof; indeed, in the form of ground-rents or annuities secured on land initial capital accumulation arises $^{81}$.

Finally, Luther acknowledges that economics does have its own mechanisms, as both the mercantilists and classical economists were to argue. His recognition is tinged with despair, to be sure, as he sees his strictures against monopolies, forestalling, and price-rigging falling upon deaf ears. That is not to say that Luther believes that economics is autonomous; of course it is not: it is part of God's plan. Luther's approach to economic life remains firmly theological. But if he rejects the Eigengesetzlichkeit of economics ${ }^{82}$, he does glimpse the Gesetzmäßigkeit of econ-

\footnotetext{
77 Habn, Bedeutung 51 f., 56.

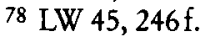

79 Fabiunke, Luther als Nationalökonom 148.

$80 \mathrm{Hahn}$, Bedeutung 52.

81 Fabiunke, Luther als Nationalökonom 102, $134 \mathrm{f}$.

${ }^{82} \mathrm{Habn}$, Bedeutung 96; Barge, Luther und der Frühkapitalismus 51.
} 
omic processes ${ }^{83}$, nowhere more clearly than in his teaching on money, even if he was only echoing what some scholastics had argued a century or more before his time.

In short, it is clear that at several points Luther touches upon issues which were to exercise political economists throughout the early modern period. Rather than describe his thinking as part-mercantilist, part-physiocrat, and part-classical economist or capitalist, it would be more useful to say that, amidst his overt hostility to the manifestations of early capitalism in his own day, Luther shows remarkable insight into the mechanisms underlying and impelling those manifestations. His response is to condemn the consequences but at the same time tentatively to elaborate principles deriving from the responsibilities of the Näbramt which were developed by cameralists and physiocrats as a solution to what they termed the requirements of Polizey.

The abiding problem with Luther is to infer his thinking from casual or oblique references, in the absence of alternatives to the malpractices which he identified. With Gaismair, our task in this regard appears more straightforward, for we can interrogate the Tirolean Constitution to ascertain his vision of a new society. But our relief is necessarily short-lived. Not only are there contradictions between the strongly egalitarian proposals concerning governance and the social order, which verge on communism, and the provisions relating to the management of the economy; even the economic clauses do not speak an unambiguous language. Jürgen Bücking was the first to recognize the discrepancy between the regulations on crafts, manufacturing, and distribution, on the one hand, and the reforms of the agrarian sector, on the other. He contrasts what he calls a market economy in agriculture, in which individual proprietors sell their produce in free competition on the open market, with state ownership and control of manufacturing production and distribution ${ }^{84}$. It is perfectly possible, of course, to argue that the ambiguities reflect the insinuations and distortions of his enemies, as does Politi, convinced that Gaismair's commitment to a Christian commonwealth was so overarching as not to permit such internal inconsistencies. In my judgement, however, this is to take too normative a view of what that commonwealth would entail in practice, especially since none of the leading Reformers disavowed private property.

Whether Bücking is wise to describe the agrarian sector of Gaismair's Tirolean ideal state as operating within a free market in the modern sense is open to some doubt, for that would imply that land, labour, and money had become fully commoditized ${ }^{85}$, which was clearly not the case. The Constitution does state that ground-rents accruing to a parasitic feudal class should be abolished, from which Bücking infers that all hereditary and fixed-term tenancies were to be transformed

83 Fabiunke, Luther als Nationalökonom 116.

84 Bücking, Gaismair 89.

85 For this fundamental insight cf. Karl Polanyi, The Great Transformation. The Political and Economic Origins of Our Time (Boston 1957) 68f., $72 \mathrm{f}$. 
into absolute private property ${ }^{86}$. Collective rights over the common land, however, exercised by the communes in villages and valley jurisdictions, were to remain. Given that Gaismair expressly says that there should be no commerce in land, I cannot see that he believes the agrarian sector should be driven by market forces alone. It seems more likely that Gaismair wishes to place obstacles in the way of agrarian entrepreneurs and capitalist farming practices such as enclosure, while protecting peasant family rights to buy and sell plots of land and to employ wage-labour where necessary (seasonally essential in viticulture).

This latent distinction between small-scale commodity producers and capitalist entrepreneurs is carried through into the mining chapter of the Constitution, where the interests of the lesser mining shareholders are addressed. Angelika Bischoff-Urack has pointed out that the Gaismair family could well have afforded to pay their mineworkers in direct wages, but chose in most cases to employ workers on fixed-term contracts (Lebenbäuer), who shouldered the risk of investment in return for a share of the ore ${ }^{87}$. These Lebenhäner may be compared with sharecroppers in an agrarian regime, and while there has been much debate whether share-cropping is characteristic of primitive subsistence agriculture or a form of early-capitalist agriculture ${ }^{88}$, there seems little doubt that in the case of mining the Lebenbäuer were in effect tied to a putting-out system (Verlag), which is always taken as the quintessence of early capitalism.

If we are willing to concede that Gaismair's agricultural and mining provisions do contain elements of petty capitalism, what are we to make of his stipulations on manufacturing and trade? Here the argument ex silentio seems justified that the centralization and nationalization of production and distribution by definition entail the abolition of individual workshop production, private ownership of the means of production, and indeed the suspension of those corporatist institutions designed to safeguard sectional interests, namely the craft guilds. In that sense Peter Blickle may well be correct to speak of the total negation of corporatism, as represented by the Ständestaat, the society of estates ${ }^{89}$. Where the Meran Articles had called for the abolition of the craft guilds, the Territorial Constitution passes over the issue in silence: it had become otiose.

But the matter is not as simple as that. The Meran Articles had insisted upon the abolition of craft guilds precisely in order to allow individuals to work freely, unfettered by corporatist restrictions on workshop size or quotas on production and labour, not in order to pave the way for a system of collectivized or socialized manufactories. If Gaismair did indeed have a hand in the Meran Articles, then his

\footnotetext{
86 'Tirolean Constitution $\$ 22$. Scott, Scribner, German Peasants' War 268; Bücking, Gaismair 88.

${ }^{87}$ Bischoff-Urack, Gaismair 25; cf. Adolf Laube, Der Aufstand der Schwazer Bergarbeiter 1525 und ihre Haltung im Tiroler Bauernkrieg, in: Dörrer, Die Bauernkriege 173.

${ }^{88}$ Frank Ellis, Peasant Economics. Farm Households and Agrarian Development (Cambridge 1988) 142-147.

89 Peter Blickle, Die Krise des Ständestaats. Tirol als Modell zur Lösung des Konflikts von 1525, in: Dörrer, Die Bauernkriege 51.
} 
thinking had certainly moved on by the time he came to draft his Territorial Constitution - though not consistently, since the interests of individual proprietors were to be upheld in agriculture and mining.

These inconsistencies have, not surprisingly, led to highly discrepant verdicts on the correct location of the Territorial Constitution within the development of political economy. One of the more dispassionate judgements is that of Ferdinand Seibt, who describes the Constitution as reflecting mittelständiscbe Verbältnisse, that is, the situation of small producers, be they peasants, artisans, or miners ${ }^{90}$. But the provisions on trade and industry do not fit this bill. These Bücking sees as embodying the principle of Gewerbesozialismus, or artisanal socialism, though elsewhere he describes Gaismair's vision of the state control of industry and marketing as reminiscent of Robert Owen's or Pierre Prudhon's banks of exchange, which would push that vision well towards what Marx called utopian socialism ${ }^{91}$.

From there it is perhaps only a small leap to combine the two elements by defining Gaismair's programme as Mittelstandssozialismus, a term once used by Arthur Schweitzer to characterize some early support for National Socialism in the Third Reich ${ }^{92}$. This suggestion by Karl-Heinz Ludwig, during discussions at the Gaismair Conference in Innsbruck in $1976^{93}$, deserves to be taken seriously, not least because Ludwig, as an expert on mining, was the first to draw attention to the fact that the mining chapter of the Territorial Constitution does not amount to a call for the wholesale nationalization of the mines. This approach is shared by Ludwig's pupil, Angelika Bischoff-Urack, though she is more inclined to describe Gaismair's vision as bourgeois rather than socialist - she emphasizes the Mittelstand at the expense of the Sozialismus ${ }^{94}$. Given its pedigree, it is no wonder that East German Marxist historians would have no truck with Mittelstandssozialismus; Adolf Laube, the one East German historian to have studied the mining industry in depth, persisted in arguing that the Tirolean Constitution contributed towards the direct promotion of capitalist development ${ }^{95}$.

90 Ferdinand Seibt, Utopica. Modelle totaler Sozialplanung (Düsseldorf 1972) 89.

91 Bücking, Gaismair 89. Cf. Karl Marx, Frederick Engels, Manifesto of the Communist Party, in: idem, Selected Works in One Volume (London 1968) 59-62. Cf. also Frederick Engels, Socialism. Utopian and Scientific, ibid. $407 \mathrm{ff}$.

92 Bischoff-Urack, Gaismair 78.

93 The term does not appear in the published proceedings of the conference, but the present writer, as a participant, vividly recalls the expression of disgust at its mention which crossed the faces of the East German scholars present. Why they should have been so disgusted is immediately apparent (apart from the Third Reich connotations), since it exactly corresponds to the way in which Marx and Engels characterized petty-bourgeois socialism in the Communist Manifesto, with which Gaismair, as a revolutionary hero of the Volksreformation, must not be tainted. Marx, Engels, Manifesto of the Communist Party $55 \mathrm{f}$.

94 Bischoff-Urack, Gaismair 76.

${ }_{95}$ Adolf Laube, Bemerkungen zum Zusammenhang von Frühkapitalismus und frühbürgerlicher Revolution, in: Gerbard Brendler, Adolf Laube (eds), Der deutsche Bauernkrieg 1524/25. Geschichte - Tradition - Lehren (Akademie der Wissenschaften der DDR: Schriften des Zentralinstituts für Geschichte 57, Berlin 1977) 63. He does not deny, however, that the mining article in the Territorial Constitution essentially mirrors the interests of the mine- 
An escape from the dilemma of how to weigh the capitalist against the socialist components of Gaismair's programme, I suggest, may be found by placing it more firmly within the context of early modern political economy. To begin with, a central strand of mercantilism is clearly foreshadowed in the Tirolean Constitution, namely the commitment to bullionism: the accumulation of reserves of precious metal, the exploration of new mines, and the insistence on a sound coinage of high silver content. At the same time, however, his commitment to agricultural improvement takes Gaismair beyond bullionism to the concerns of the physiocrats, who were openly critical of monetarist theories of value.

Again, the strongly autarkic leanings of the Tirolean Constitution find a ready parallel in mercantilist doctrines, yet Gaismair embraces a customs policy which is directly contrary to mercantilism, to wit, the encouragement of imports and restrictions on exports. Gaismair realizes, as a child of Tirol, a major artery of trade, that not all commodities can be supplied from within the territory, and he is much more lenient towards the import of spices as a luxury product than Luther ever was. Nevertheless, the promotion of the domestic economy in general, which will help to ensure cheap prices and full employment, places Gaismair squarely in the mercantilist camp. Thus I find it hard to agree with Frank Ganseuer when he contends that Gaismair recast the pre-capitalist maxim of sufficiency - zimliche noturft - to apply no longer to individuals or families, but to the territory as a whole. The concept of zimliche noturft appears nowhere in the Constitution, which refers twice, in a perfectly neutral sense, to gemainer Lands notturft, and once, in the mining chapter, to the desirability of achieving a zimlich einkbumen. To interpret this latter phrase as suggesting a moderate, proportionate income rather than an excessive one not only conflicts with Gaismair's declared bullionism - the accumulation of a treasury of wealth - but also with the call to prospect for new sources of precious metal. The most one can say is that Ganseuer is certainly right not to see in Gaismair an apologist for unrestrained capitalism ${ }^{96}$.

Whether the autarkic strains in Gaismair's programme are the outflow of a general vision of a closed society is another question. Bücking certainly makes a case for seeing the Tirolean Constitution as a manifesto for order, harmony, and balance - in short, for conformity and uniformity -, and he is right to discern parallels with More's Utopia, Eberlin von Günzburg's Wolfaria, or Tommaso Campanella's The City of the Sun ${ }^{97}$. But if this is a closed society, then it is one without the stuffy conformism and moral rigorism of those utopias. The specifically econ-

workers and smaller mining shareholders. Laube, Aufstand 182. That surely confirms its petty-bourgeois character!

${ }_{96}$ Ganseuer, Staat des "gemeinen Mannes“ 187f., 203. His general view is that the Tirolean Constitution was mostly conservative, and indeed potentially ruinous for Tirol's economy. Ibid. 196.

97 Bücking, Gaismair 90 . The parallels with More’s Utopia are emphasized by Stella, Il „Bauernführer" $151 \mathrm{f} ., 228,230$, who is content to regard the Territorial Constitution as the embodiment of popular republicanism inspired by the political communalism of the Swiss and the religious communalism of $Z$ wingli. This approach, alas, ignores the internal contradictions identified by Bücking, and the family interests identified by Bischoff-Urack. 
omic provisions of the Tirolean Constitution are surely much less absolute, and more concerned to protect the rights and property of individuals, and to encourage initiative, knowledge and improvement ${ }^{98}$ : perhaps more like Voltaire's Eldorado.

In drawing attention to the parallels between Luther's and Gaismair's thought and the economic doctrines which prevailed in early modern Europe, I am not seeking to brand them as mercantilists, cameralists, or physiocrats avant la lettre, for that would simply be to exchange one set of misleading labels for another, and in any case, as I have stressed, there are significant divergences as well as congruences. Yet we must not at the same time forget the strands in their economic thinking which point beyond these doctrines to the dawn of classical economics. Their attack on finance capital and oligopolies chimed with the conventional wisdom of their day - only Conrad Peutinger offered a sustained defence of the trading companies on the basis of free-market principles ${ }^{99}$ - but that must not be allowed to obscure their underlying endorsement of petty capitalism, which certainly went beyond any precept of ziemliche Nabrung, or Hausnotdurft, to use Renate Blickle's phrase.

Much more significant, however, was the similarity of outlook over the nature of consumption and demand between the two Reformers, on the one hand, and the seventeenth-century precursor of the physiocrats in France, Pierre le Pesant, seigneur de Boisguillebert, and the father of classical economics in the eighteenth century, Adam Smith. What linked all four men - with von Justi straddling them was the common assumption that the true source of a nation's prosperity lay in the land. In rejecting the bullionist view of wealth, Boisguillebert declared: „One can imagine what abundance of wealth would be seen if all things, agricultural land as well as everything else, were as valuable as it is possible for nature to make them." 100 A century later, in The Wealth of Nations, Adam Smith, seeking to expose the fallacies of mercantilism, argued instead that ,the real wealth of the country [is] the annual produce of its land and labour", and added with emphasis a few lines later: „The land constitutes by far the greatest, the most important, and the most durable part of the wealth of every extensive country."101 From their dif-

${ }^{98}$ Blaich sees in the Territorial Constitution the blueprint for a Zentralverwaltungswirtschaft, i.e. a centrally directed planned economy. Blaich, Wirtschaftspolitik 131. But this view is too one-sided.

99 Idem, Reichsmonopolgesetzgebung 74-80. The defence was based on the contention that the companies, in organization and functioning, were not in fact monopolistic at all, not that monopolies were justifiable.

100 Pierre le Pesant, Seigneur de Boisguillebert, Dissertation sur la nature des richesses, de l'argent et des tributs, in: Économistes Financiers du XVIIIe siècle. Ed. E. Daire (Paris 1843) 420. Cited in: Hazel van Dyke Roberts, Boisguilbert. Economist of the Reign of Louis XIV (New York 1935) 291.

${ }_{101}$ Adam Smith, An Inquiry into the Nature and Causes of the Wealth of Nations (Everyman edn, London 1991) I, xi 222. That admittedly has to be set against his critique at the end of Book IV, in which he opposed those such as Colbert and Quesnay who believed that the produce of the land was the sole or the principal source of wealth. Ibid. IV, ix $596 \mathrm{ff}$. 
ferent perspectives Luther and Gaismair shared those sentiments in varying measure. Luther upheld the primacy of nature and the intrinsic virtue of agricultural labour, though he stopped short of embracing a doctrine of agricultural commercialization or diversity. Gaismair, by contrast, from the perspective of a region with an already commercialized rural economy, did so with enthusiasm, a point often overlooked by those who focus only on his mining interests and consequent attachment to bullionism. In other words, behind the façade of commitment to a rural arcadia, shared by almost all Reformers, lay an appreciation that an agrarian regime could not simply be equated with economic self-sufficiency or social egalitarianism.

What mattered ultimately, however, were the lessons to be drawn from this belief. Both Boisguillebert and Adam Smith regarded underconsumption (or, as we might say, lack of demand) as the real brake upon economic growth, though the French Catholic aristocrat was perhaps more insistent on this point than the frugal Scots Calvinist ${ }^{102}$. And, in contradistinction to the puritan tradition of asceticism and self-denial, upon which the entire cultural equation of Protestantism and capitalism has commonly been erected, Luther and Gaismair drew the same conclusion. Luther, conventionally in his day, denounced luxury and ostentation, but he was no opponent of honest food and drink, decent housing and clothing, let along the pleasures of music and the bed - in short, he was not a puritan ${ }^{103}$. And neither was Gaismair, whose centralized manufactory in Trent was to produce a range of luxury goods alongside more basic commodities, and who spent his exile on Venetian soil living in considerable style as a mercenary captain, eating off silver plates and riding out with a mounted escort, even before he became a "cavalier of the Strozzi“i104.

We are all familiar with the high road leading straight from Protestantism to capitalism, whose course lay outside Germany. As Marx put it fifty years before Max Weber (though the latter could not have known of it): „The cult of money has its asceticism, its self-denial, its self-sacrifice - economy and frugality, contempt for mundane, temporal and fleeting pleasures: the chase after eternal treasure. Hence the connection between English Puritanism or also Dutch Protestantism, and money-making. " 105 My purpose is to draw attention to another road, the low road, badly signposted and beset with twists and turns, which crossed the early modern social and economic landscape. That road was neither peculiar to Germany, nor travelled by the adherents of Protestantism alone. And yet, in the German-speaking lands, many of the pathbreakers, groping their way through the

102 Roberts, Boisguilbert 287.

103 Cf. Fabiunke, Luther als Nationalökonom 149.

104 Bücking, Gaismair 104; Aldo Stella, La Rivoluzione Contadina del 1525 e l'Utopia di Michael Gaismair (Padua 1975) 170; idem, Michael Gaismair. „Cavaliere degli Strozzi“ e la sua famiglia durante il soggiorno padovano (1527-1532), in: Dörrer, Die Bauernkriege 118; idem, Il „Bauernführer“ 205.

105 Marx, Grundrisse (English transl.) 232. The Grundrisse were not published until 1939 (and then only incompletely), nineteen years after Weber's death. 
thickets of mercantilism and cameralism, were Protestant in origin, even if on occasion they found service at Catholic courts. There is no need to claim Luther - or Gaismair, or indeed any other Protestant Reformer or political theorist - as the forerunner of the classical free-market economic thought of Ricardo and Smith, not least because these latter eminences have been toppled from their pedestals as the pioneers of modern political economy by the discovery that the scholastics had said most of it before them. Of greater interest is the manner in which Smith absorbs and criticizes often contradictory ideas, mercantilist and physiocrat, bound together in the loose bundle of early modern economic thought. Those contradictions rested in part on an imperfect understanding of economic laws, but derived also from the discrepant elements within the early modern economy itself. Both aspects are reflected in the thought of Luther and Gaismair, and it is an intellectual foreshortening to deny or elide the unevenness in their thinking, since that unevenness mirrored the historical circumstances which they themselves experienced and confronted. 